\title{
Anti-Hyperglycemic and Antioxidant Effect of Saraca asoca (Roxb. De Wilde) Flowers in Streptozotocin-Nicotinamide Induced Diabetic Rats: A Therapeutic Study
}

\author{
Shanti Bhushan Mishra ${ }^{1 *}$ and Vijayakumar $\mathbf{M}^{2}$ \\ ${ }^{1}$ Department of Pharmacognosy, United Institute of Pharmacy, Allahabad, India \\ ${ }^{2}$ The Himalaya Drug Company, Bangalore, India
}

\begin{abstract}
$50 \%$ Ethanolic extract of Saraca asoca Roxb. de Wilde flowers (SAE) was screened for its antihyperglycemic and antioxidant effect in streptozotocin-nicotinamide induced diabetic rats. Phytochemical analysis of SAE revealed the presence of phenolic compounds phytosterol, flavonoids and saponins. After the administration of extract 200 $\mathrm{mg} / \mathrm{kg}$ body weight/day) in diabetic rats has improved the elevated levels of blood glucose $(p<0.01)$. The decreased activities of key antioxidant enzymes such as superoxide dismutase, catalase, glutathione peroxidase, glutathione reductase and glutathione in diabetic rats were brought back to near normal range upon SAE treatment. Our studies demonstrate the anti-hyperglycemic and anti-oxidative potential of Saraca asoca which could exert sympathetic effects against the diabetes and associated free radicals complications.
\end{abstract}

Keywords: Saraca asoca; Antidiabetic; Streptozotocin; Ethanolic extract; Histopathology

\section{Introduction}

Diabetes mellitus is a disease that has been characterized by a series of complications affecting several tissues in the body. Free radicals have been implicated in the pathophysiology of diabetes and oxidative stress may be a common pathway linking diverse mechanisms for the complications in diabetes. The protection of cells from oxidative stress is essential and under normal conditions adequate protection is provided by the antioxidant systems [1]. Mammalian cells possess elaborate defense mechanisms for free radical detoxification involving metabolic enzymes such as superoxide dismutase (SOD), catalase (CAT) and glutathione peroxidase. (GPx) Non-enzymatic molecules, including thioredoxin, thiols, vitamins $\mathrm{E}, \mathrm{C}$ and trace metals, such as selenium function as direct scavengers of ROS [2].

In recent years, interest in finding naturally occurring antioxidants that can protect against oxidative stress has increased considerably, with a view to their use in foods or as medicinal formulations to replace synthetic antioxidants [3]. Natural antioxidants have been reported to have a wide range of biochemical activities, including inhibition of ROS generation, direct or indirect scavenging of free radicals, and alteration of intracellular redox potential [4]. The use of plants as source of drugs and their validation is gaining increasing attention [5]. Because of this bleak forecast, research on anti-diabetic plants has been strongly encouraged by World Health Organization. Ashoka is wonderful herb that claims to cure several diseases. Leaves possess blood purifying properties, CNS depressant activity, anti-platelet aggregation activity $[6,7]$ and seeds have antipyretic, anti-arthritic action [8,9]. Flowers pounded in water are used in hemorrhagic dysentery [10,11], and the dried flowers in diabetes [12]. Previously isolated constituents of the plant are Flavonoids, lignin glycosides and Gallic acid [13,14]. Although infusion of $S$. asoca flowers has been used to treat diabetes as a folk medicine, no scientific report exists for the use of this plant to treat diabetes. Therefore first time an attempt has been made for investigating its antihyperglycemic activity and effects on total lipid, cholesterol triglycerides and enzymatic parameters as scientific evidence.

\section{Material and Methods}

\section{Plant material}

Saraca asoca Roxb. de Wilde (Caesalpiniaceae) fresh flowers collected from NBRI campus, Lucknow in the month of March and authenticated by a taxonomist with voucher specimen number CIFRB-2-126-3.

\section{Extract preparation}

The freshly collected flowers $(2 \mathrm{~kg})$ of $S$. asoca were first air-dried and then dried in tray drier under control conditions and powdered. The powdered flowers $(950 \mathrm{~g})$ were macerated with petroleum ether to remove fatty substances; the marc was further exhaustively extracted with of $50 \%$ ethanol for 3 days ( 3 X $3 \mathrm{~L}$ ) by cold percolation method and centrifugation at $10,000 \mathrm{rev} / \mathrm{min}$. The extract was separated by filtration and concentrated on rotavapour (Buchi, USA) and then dried in lyophilizer (Labconco, USA) under reduced pressure and thus 100.0 $\mathrm{g}$ of solid residue (yield $10 \% \mathrm{w} / \mathrm{w}$ ) was obtained.

\section{Phytochemical screening}

Phytochemical screening of ethanolic extract was carried out by standard procedures [15], which revealed the presence of chemical constituents like fixed oil, phenolic compounds phytosterol, flavonoids and saponins.

*Corresponding author: Shanti Bhushan Mishra, Assistant professor, Department of Pharmacognosy, United Institute of Pharmacy, Allahabad -211010, India, Tel.: +918004279457; Fax: 91(0532) 2687142; E-mail: shantipharma15@gmail.com

Received October 06, 2014; Accepted November 27, 2014; Published November 29, 2014

Citation: Mishra SB, Vijayakumar M (2014) Anti-Hyperglycemic and Antioxidant Effect of Saraca asoca (Roxb. De Wilde) Flowers in Streptozotocin-Nicotinamide Induced Diabetic Rats: A Therapeutic Study. J Bioanal Biomed S12: 003. doi:10.4172/1948-593X.S12-003

Copyright: (c) 2014 Mishra SB, et al. This is an open-access article distributed under the terms of the Creative Commons Attribution License, which permits unrestricted use, distribution, and reproduction in any medium, provided the original author and source are credited. 
Citation: Mishra SB, Vijayakumar M (2014) Anti-Hyperglycemic and Antioxidant Effect of Saraca asoca (Roxb. De Wilde) Flowers in StreptozotocinNicotinamide Induced Diabetic Rats: A Therapeutic Study. J Bioanal Biomed S12: 003. doi:10.4172/1948-593X.S12-003

\section{Experimental animals}

Healthy adult Wistar albino rats weighing 200-250 g were used for the pharmacological studies. The animals were housed in polypropylene cages, maintained under standard conditions (12/12 h light and dark) at $25 \pm 3^{\circ} \mathrm{C}$ and $35-60 \%$ humidity. They were fed with standard rat pellet diet (Amrut, India) and water ad libitum. The Institutional Animal Ethical Committee, United Institute of Pharmacy, Allahabad, India (No. 1451/PO/a/11/CPCSEA) has approved the study.

\section{Oral acute toxicity study}

The lethal median dose $\left(\mathrm{LD}_{50}\right)$ determination was done in rats by OECD guidelines 423 [16]. A single dose of the extracts $(5 \mathrm{mg} / \mathrm{kg}, 50$ $\mathrm{mg} / \mathrm{kg}, 300 \mathrm{mg} / \mathrm{kg}$ and $2000 \mathrm{mg} / \mathrm{kg}$ ) in appropriate quantity of water was given orally by gavage to different group of animals (three each). The animals were allowed free access to water and food. However, all the animals were deprived of food for $2 \mathrm{hr}$ before and $4 \mathrm{hr}$ after dosing. The animals were continuously monitored during first $4 \mathrm{hrs}$ and every one-hour during the first $12 \mathrm{hrs}$ for any adverse effects. Later they were monitored (daily twice) for any abnormal changes throughout the study period (14 days).

\section{Experimental induction of diabetes}

Streptozotocin (STZ) was freshly dissolved in $(0.1 \mathrm{M}, \mathrm{pH} 4.5)$ citrate buffer and Nicotinamide was dissolved in normal physiological saline and maintained on ice prior to use. All animals were allowed to adapt to cages for 3 days, after which they were fasted overnight. Non-insulindependent diabetes mellitus was induced in overnight fasted rats by a single intraperitoneal injection of Streptozotocin (60 mg/kg b.w), 15 min after the intraperitoneal administration of nicotinamide $(120 \mathrm{mg} /$ $\mathrm{kg}$ b.w) all animals were given free access to food and water. Blood glucose levels were measured 2 days after STZ injection and used as parameters to obtain matching pairs of rats with diabetes of similar level of severity. Only rats with fasting blood glucose levels greater than 220 $\mathrm{mg} / \mathrm{dl}$ were considered to be diabetic and were used in the experiment. The mean blood concentration of glucose in normoglycemic rats was $85 \mathrm{mg} / \mathrm{dl}$. The animals were randomly assigned to five different groups i.e. group I to V. Group I served as control containing 6 normal rats [17].

\section{Experimental design}

Five groups of rats were used to study the effect of $50 \%$ ethanolic extract of Saraca asoca. Each group consisting of six rats.

Group I-Control rats received vehicle normal saline solution solution

Group II-Diabetic control rats received vehicle normal saline

Group III and IV-Diabetic rats treated with extract $100 \& 200 \mathrm{mg} /$ $\mathrm{kg}$ body weight respectively.

Group V-Diabetic rats treated with standard drug Glibenclamide $600 \mu \mathrm{g} / \mathrm{kg}$ body weight

The vehicles and the drugs were administered orally using oral gavage tube daily for three weeks. Blood samples were collected for the measurement of blood glucose level from the tail vein on 0 day, $7^{\text {th }}, 14^{\text {th }}$ and $21^{\text {st }}$ day. The blood glucose level was determined by glucometer (one touch). The values of sample treated were compared with that of the standard group which was treated with Glibenclamide. Then the animals were sacrificed by cervical dislocation. The liver, kidney and pancreas were exposed and perfused with cold saline phosphate buffer of pH 7.4 for histopathological examination. Blood free liver and kidney were taken away and homogenized in a glass Teflon homogenizer separately $(10 \% \mathrm{w} / \mathrm{v})$. Incubation was done at $37^{\circ} \mathrm{C}$ under controlled conditions for biochemical estimation. The collected blood samples were immediately centrifuged at $2500 \mathrm{rpm}$ for $15 \mathrm{~min}$. The serum separated was collected in fresh serum tubes and stored in refrigerator $\left(2-4^{\circ} \mathrm{C}\right)$ after tightly capped. Effect of test extracts on serum glucose, antioxidant enzymes and lipid profile were assessed.

\section{In-vivo antioxidant activity in diabetic rats}

Measurement of Catalase (CAT), Superoxide dismutase (SOD), Glutathione -S-transferase (GST), Reduced glutathione (GSH) and Glutathione peroxidase (GPx) were determined for ascertain its antioxidant activity by standard procedure of Pari [18].

\section{Histopathological examination}

At the end of the treatment period the control as well as treated rats were sacrificed by using cervical dislocation and the pancreas was dissected out and part of pancreatic tissue was immediately fixed in bouin's fluid for $24 \mathrm{hr}$ and washed in running tap water to remove colour of bouin's fluid and dehydrated in alcohol in ascending and descending order, embedded in paraffin and cut at $5 \mu \mathrm{m}$ in a rotary microtome. These sections were then deparaffinized in xylene and stained with hematoxylin-eosin and mounted with canada balsam. The histopathological slides were examined and photographs were captured with a digital stereomicroscope (Olympus, B061) [19].

\section{Statistical analysis}

The statistical analysis of all the pharmacological analysis was carried out using GraphPad Prim version 3.03 for windows. The values are represented as mean $\pm S$. D. for six rats data were analyzed by ANOVA with post-hoc difference was analysed using Newman-keuls method.

\section{Results}

\section{Acute toxicity study}

The $\mathrm{LD}_{50}$ determination was done by OECD guidelines 423 . The $\mathrm{LD}_{50}$ of the $50 \%$ ethanolic extract of flowers of Saraca asoca was found to be $1000 \mathrm{mg} / \mathrm{kg}$. One-tenth of the maximum dose of the extract tested was selected for the study, i.e. $100 \mathrm{mg} / \mathrm{kg}$ and double strength $200 \mathrm{mg} /$ $\mathrm{kg}$

\section{Antihyperglycemic activity}

There was a significant elevation in serum glucose, total cholesterol, triglycerides, and total lipid while the enzymatic and non enzymatic parameters viz. GSH, GST, GPx, CAT and SOD significantly decreased in the diabetic control group animals. (Figure 1) showed that the $50 \%$ ethanolic extract of flowers of $S$. asoca tended to bring serum glucose towards normal value at dose of $200 \mathrm{mg} / \mathrm{kg}$ after 21 days treatment $(228.33-126.77)(\mathrm{p}<0.01)$ whereas Glibenclamide lowers significant blood glucose level after 21 days treatment $(228.33-94.68)(\mathrm{p}<0.001)$. (Figure 2) showed the administration of the S. asoca extract $(200 \mathrm{mg} / \mathrm{kg}$ body wt.) trivial change serum triglycerides $(115.66-101.46 ; \mathrm{p}<0.05)$ total cholesterol (153.66-145.16) and total lipid (148.83-123.25; $\mathrm{p}<0.001)$ levels in diabetic rats.

\section{Effect of extract on antioxidant status}

The effect of $S$. asoca extract on antioxidant status, the activities of enzymatic antioxidants SOD, CAT, GPx and GST and non-enzymatic 
Citation: Mishra SB, Vijayakumar M (2014) Anti-Hyperglycemic and Antioxidant Effect of Saraca asoca (Roxb. De Wilde) Flowers in StreptozotocinNicotinamide Induced Diabetic Rats: A Therapeutic Study. J Bioanal Biomed S12: 003. doi:10.4172/1948-593X.S12-003

Page 3 of 5

antioxidant GSH were estimated and results were shown in (Table 1). The activities of enzymatic and levels of non-enzymatic antioxidant were significantly decreased in diabetic control rats. After 21 days

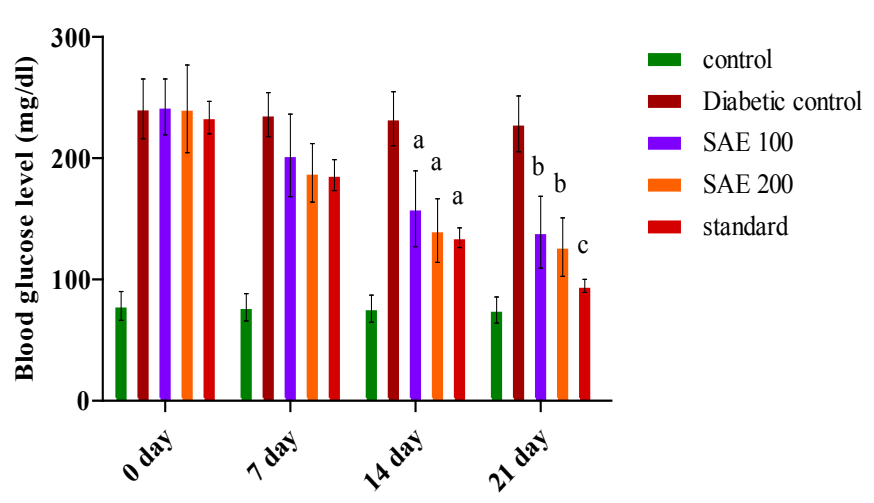

The value represents the means \pm S.D. for 6 rats per group. ${ }^{a} p<0.05,{ }^{b} p<0.01$ and ${ }^{c} p<0.001$ compared to diabetic control group. ${ }^{2} p<0.001$ as compared to normal group.

Figure 1: Antihyperglycemic activity of extract of $S$. asoca.

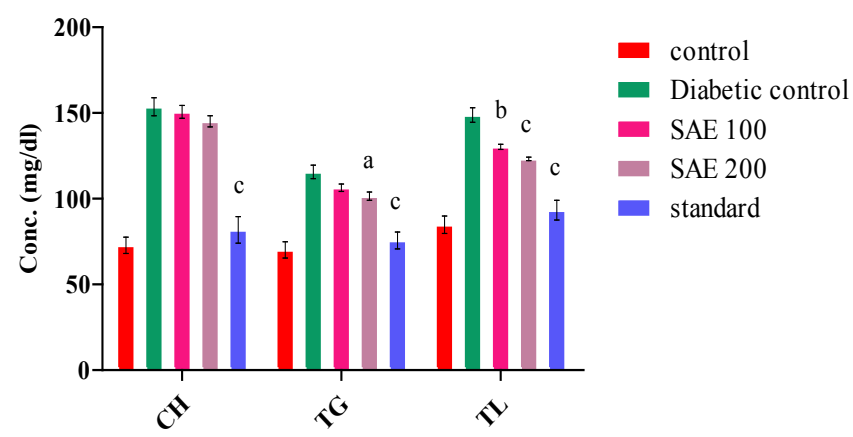

The value represents the means \pm S.D. for 6 rats per group. ${ }^{a} p<0.05,{ }^{b} p<0.01$ and ${ }^{c} p<0.001$ compared to diabetic control group. ${ }^{2} p<0.001$ as compared to normal group.

Figure 2: Effects of extract of $S$. asoca on the total cholesterol, triglyceride and lipid level treatment with $200 \mathrm{mg} / \mathrm{kg}$ of extract, there is significant increase in GPx and CAT level in liver 5.19 to 6.42 and 38.67 to 58.45 respectively $(\mathrm{p}<0.001)$, where as other parameters showed trivial change as compared with diabetic control.

\section{Histopathological investigation}

In (Figure 3), microscopically examined pancreas section of control group (3A) showed Islets are normal. The architecture is preserved. The acini are lined by round to oval cells with moderate cytoplasm and small round to oval nuclei where as in diabetic control group (3B) Islets shows depletion of cells. The architecture is preserved. The acini are lined by round to oval cells with moderate cytoplasm and small round to oval nuclei. In case of extract $100 \mathrm{mg} / \mathrm{kg}$ treated group (3C) the architecture is normal. The islets are normal. The islets show depletion of the acinar cells. The acinar cells show moderate cytoplasm and round to oval nuclei. There is no evidence of inflammation. 50\% ethanolic extract $200 \mathrm{mg} / \mathrm{kg}$ treated group (3D). The acinar cells show moderate cytoplasm and round to oval nuclei. There is no evidence of inflammation, while in standard treated group (3E), there is mild infiltrate of lymphocytes at some foci. The acini are lined by round to oval cells with moderate cytoplasm and small round to oval nuclei.

\section{Discussion}

Diabetes produces substantial changes in intracellular metabolism in many tissues including liver and kidney [20]. In the present study, STZ treatment caused a significant depletion of both non-enzymatic and enzymatic antioxidants of liver and kidney tissues [21,22]. SOD is an enzymatic antioxidant which reduces superoxide radical to hydrogen peroxide, CAT in turn involved in the reduction of hydrogen peroxide [23]. A decrease in the activities of these antioxidant enzymes in tissues can lead to the formation of superoxide anion and hydrogen peroxide which can later form hydroxyl radical. GSH-metabolizing enzymes, GPx and GST work in concert with glutathione in the decomposition of hydrogen peroxide and other organic hydroperoxides to non-toxic products, respectively, at the expense of reduced glutathione. Reduced activities of GPx and GST observed were due to inactivation of these enzymes by ROS. Treatment with $S$. asoca showed increased activities of enzymatic antioxidants, which might be due to the presence of phytosterols and flavonoids. Flavonoids present in the flower-extract scavenge the free radicals generated during diabetes, as they are well known for their antioxidant properties [24,25]. Our investigations

\begin{tabular}{|c|c|c|c|c|c|}
\hline Parameters & Normal control & Diabetic control & $\begin{array}{c}\text { SAE treated } \\
(100 \mathrm{mg} / \mathrm{kg} \mathrm{BW})\end{array}$ & $\begin{array}{c}\text { SAE treated } \\
(200 \mathrm{mg} / \mathrm{kg} \mathrm{BW})\end{array}$ & $\begin{array}{c}\text { Glibenclamide treated } \\
(600 \mu \mathrm{g} / \mathrm{kg})\end{array}$ \\
\hline \multicolumn{6}{|c|}{ GSH (mM of DTNB conjugated/mg protein) } \\
\hline $\begin{array}{l}\text { Liver } \\
\text { Kidney }\end{array}$ & $\begin{array}{l}129.67 \pm 2.66 \\
118.77 \pm 2.31\end{array}$ & $\begin{array}{l}74.23 \pm 1.51^{z} \\
46.17 \pm 2.49^{z}\end{array}$ & $\begin{array}{l}82.46 \pm 2.27^{a} \\
62.15 \pm 3.56\end{array}$ & $\begin{array}{l}98.123 .34^{c} \\
69.38 \pm 2.78\end{array}$ & $\begin{array}{c}130.56 \pm 1.41^{\mathrm{c}} \\
95.17 \pm 2.55(\mathrm{NS})\end{array}$ \\
\hline \multicolumn{6}{|c|}{ GST ( $\mu$ mol of CDNB-GSH conjugate formed $/ \mathrm{min} / \mathrm{mg}$ protein) } \\
\hline $\begin{array}{l}\text { Liver } \\
\text { Kidney }\end{array}$ & $\begin{array}{l}6.75 \pm 0.97 \\
6.88 \pm 0.34\end{array}$ & $\begin{array}{l}3.42 \pm 0.18^{z} \\
2.66 \pm 0.27\end{array}$ & $\begin{array}{l}3.56 \pm 0.83^{b} \\
3.09 \pm 0.54^{a}\end{array}$ & $\begin{array}{l}3.98 \pm 0.28^{c} \\
3.68 \pm 0.38^{b}\end{array}$ & $\begin{array}{l}5.12 \pm 0.11^{\mathrm{b}} \\
3.76 \pm 0.91^{\mathrm{b}}\end{array}$ \\
\hline \multicolumn{6}{|c|}{ GPx ( $\mu$ g glutathione consumed/ min/mg protein) } \\
\hline $\begin{array}{l}\text { Liver } \\
\text { Kidney }\end{array}$ & $\begin{array}{l}9.38 \pm 0.91 \\
7.33 \pm 0.14\end{array}$ & $\begin{array}{l}5.19 \pm 0.88^{z} \\
4.99 \pm 1.01^{y}\end{array}$ & $\begin{array}{l}5.82 \pm 0.76^{b} \\
5.08 \pm 0.14^{a}\end{array}$ & $\begin{array}{l}6.42 \pm 0.54^{c} \\
5.92 \pm 0.26^{c}\end{array}$ & $\begin{array}{l}7.24 \pm 0.61^{\mathrm{b}} \\
5.66 \pm 0.58^{\mathrm{a}}\end{array}$ \\
\hline \multicolumn{6}{|c|}{ CAT ( $\mu \mathrm{mol}$ of $\mathrm{H}_{2} \mathrm{O}_{2}$ consumed/ min/mg protein) } \\
\hline $\begin{array}{l}\text { Liver } \\
\text { Kidney }\end{array}$ & $\begin{array}{l}71.25 \pm 2.17 \\
38.33 \pm 1.22\end{array}$ & $\begin{array}{l}38.67 \pm 1.92^{z} \\
20.55 \pm 1.75^{z}\end{array}$ & $\begin{array}{l}44.32 \pm 2.59^{\mathrm{b}} \\
21.26 \pm 1.08^{\mathrm{a}}\end{array}$ & $\begin{array}{l}58.45 \pm 1.26^{\mathrm{c}} \\
28.52 \pm 1.41^{\mathrm{c}}\end{array}$ & $\begin{array}{l}65.31 \pm 2.56^{c} \\
35.24 \pm 1.81^{c}\end{array}$ \\
\hline \multicolumn{6}{|c|}{$\mathrm{SOD}(\mathrm{U} / \mathrm{min} / \mathrm{mg} / \mathrm{Hb})$} \\
\hline Erythrocytes & $6.34 \pm 0.19$ & $3.41 \pm 0.22^{z}$ & $5.97 \pm 0.62^{b}$ & $5.32 \pm 0.43^{c}$ & $4.28 \pm 0.24^{b}$ \\
\hline
\end{tabular}

The values represent the means $\pm S$. D. for six rats per group. ${ }^{a} p<0.05,{ }^{b} p<0.01$ and ${ }^{c} p<0.001$ compared to diabetic control group. ${ }^{y} p<0.01$, ${ }^{z} p<0.001$ as compared to normal; SOD: superoxide dismutase; GSH: Glutathione; GPx: glutathione peroxidase; GST: glutathione-S-transferase; CAT: Catalase.

Table 1: Effect of $S$. asoca extract on antioxidant enzyme activities in STZ-nicotinamide diabetic rats. 
Citation: Mishra SB, Vijayakumar M (2014) Anti-Hyperglycemic and Antioxidant Effect of Saraca asoca (Roxb. De Wilde) Flowers in StreptozotocinNicotinamide Induced Diabetic Rats: A Therapeutic Study. J Bioanal Biomed S12: 003. doi:10.4172/1948-593X.S12-003

Page 4 of 5

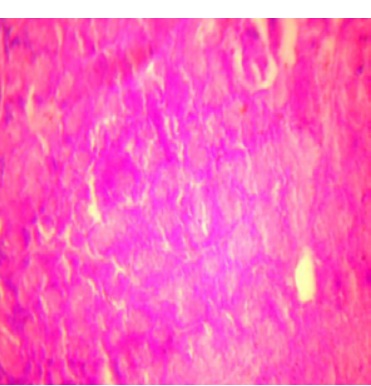

A

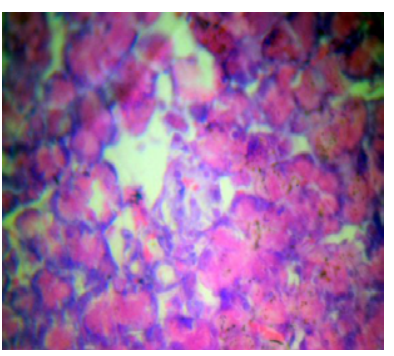

C

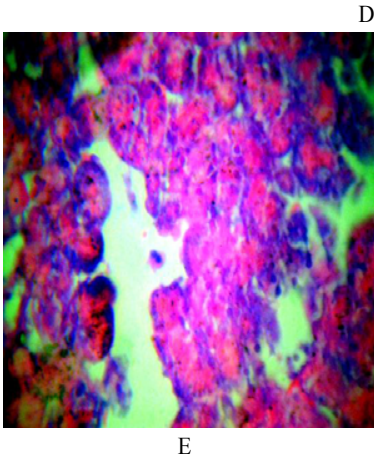

Figure 3: Histopathology of pancreas.

indicate the efficiency of the extract in the maintenance of blood glucose levels in streptozotocin-nicotinamide induced diabetic rats. Administration of aqueous ethanolic extract of $S$. asoca to diabetic rats showed a moderate decrease in the levels of blood glucose. The possible mechanism by which $50 \%$ ethanolic extract brings about its hypoglycemic action in diabetic rats may be by potentiating the insulin effect of plasma by increasing either the pancreatic secretion of insulin from the existing beta cells or by its release from the bound form. This is also evidenced by histopathological examination of pancreas showing expansion of islet cells, which cause more insulin secretion.

\section{Conclusion}

The current study provides some useful insight into the antihyperglycemic potency of Saraca asoca flowers in streptozotocin -nicotinamide induced diabetes. However, we suggest that further work should be carried out at molecular level to find out the absolute mechanism of action of plant $S$. asoca in experimental diabetes.

\section{Acknowledgement}

The authors sincerely thank to Dr. Sayyada Khatoon Scientist, National Botanical Research Institute, Lucknow for the authentication of plant material and Dr. Alok Mukerjee, Principal, United Institute of Pharmacy, Allahabad, for providing all the animal house facilities to carryout clinical studies.

\section{References}

1. Bajpai M, Pande A, Tewari SK, Prakash D (2005) Phenolic contents and antioxidant activity of some food and medicinal plants. Int J Food Sci Nutr 56 287-291.

2. Abdollahi M, Larijani B, Rahimi R, Pooneh S (2005) Role of oxidative stress in osteoporosis. Therapy 2: 787-786.

3. Fraga CG (2010) Plant Phenolics and Human Health: Biochemistry, Nutrition and Pharmacology. John Wiley \& Sons, Inc: Hoboken, New Jersey p. 270-273.

4. Mukherjee PK, Kumar V, Mal M, Peter JH (2007) Acorus calamus: Scientific validation of ayurvedic tradition from natural resources. Pharm Biol 45: 651656.

5. Rates SM (2001) Plants as source of drugs. See comment in PubMed Commons below Toxicon 39: 603-613.

6. Verma A, Jana GK, Sen S, Chakraborty R, Sachan S, et al. (2010) Pharmacological evaluation of Saraca indica leaves for central nervous system depressant activity in mice. J Pharm Sci and Res 2: 338-343.

7. Kalakotla S, Mohan GK, Sandhya rani M, Pravallika PL (2014) Phytochemica screening and in-vitro anti-platelet aggregation activity of Saraca indica Linn. Indo Am J Pharm Res 4: 2730-2735.

8. Sasmal S, Majumdar S, Gupta M, Mukherjee A, Mukherjee PK (2012) Pharmacognostical, phytochemical and pharmacological evaluation for the antipyretic effect of the seeds of Saraca asoca Roxb. Asian Pac J Trop Biomed 2: 782-786.

9. Gupta M, Sasmal S1, Mukherjee A2 (2014) Therapeutic Effects of Acetone Extract of Saraca asoca Seeds on Rats with Adjuvant-Induced Arthritis via Attenuating Inflammatory Responses. ISRN Rheumatol 2014: 959687.

10. A Dictionary of Indian raw materials and industrial products (2009) Wealth of India, Council of Scientific and Industrial Research, New Delhi p. 232-234.

11. Kirtikar K, Basu BD (2006) Indian medicinal plants. Published by Int. book distributors, Dehradun, India p. 883-884.

12. Chhetri DR, Parajuli P, Subba GC (2005) Antidiabetic plants used by Sikkim and Darjeeling Himalayan tribes, India. J Ethnopharmacol 99: 199-202.

13. Sadhu SK, Khatoon A, Phattanawasin P, Takashi O, Masami I (2007) Lignan glycoside and flavonoids from Saraca asoca with antioxidant activity. J Nat Med 61: 480-482.

14. Saha J, Mitra T, Gupta K (2012) Phytoconstituents and HPTLC analysis in saraca asoca (Roxb) Wilde. Int J Pharm Pharm Sci 4: 96-99.

15. Kokate CK, Purohit AP, Gokhale SB (2008) Pharmacognosy, Nirali prakashan, India p. 607-611.

16. Environment Directorate (2000) OECD. Guidelines number 423 for the testing of chemicals revised draft guideline 423 Paris.

17. Shirwaikar A, Rajendran K, Punitha IS (2005) Antidiabetic activity of alcoholic stem extract of Coscinium fenestratum in streptozotocin-nicotinamide induced type 2 diabetic rats. J Ethnopharmacol 97: 369-374.

18. Murugan P, Pari L (2006) Antioxidant effect of tetrahydrocurcumin in streptozotocin-nicotinamide induced diabetic rats. Life Sci 79: 1720-1728.

19. Culling CFA (1974) Handbook of histopathological and histochemical techniques. Butterworth \& Co Ltd, London, p. 194-196.

20. Rifikin H, Porte D (1990) Diabetes Mellitus: Theory and Practice. Elsevier, New York.

21. Ramesh B, Pugalendi KV (2006) Antioxidant role of Umbelliferone in STZdiabetic rats. Life Sci 79: 306-310.

22. Mishra SB, Verma A, Mukerjee A, Vijayakumar M (2011) Anti-hyperglycemic activity of leaves extract of Hyptis suaveolens L. Poit in streptozotocin induced diabetic rats. Asian Pac J Trop Med 4: 689-693.

23. Halliwell B, Gutteridge JM (1984) Lipid peroxidation, oxygen radicals, cell damage, and antioxidant therapy. See comment in PubMed Commons below Lancet 1: 1396-1397. 
Citation: Mishra SB, Vijayakumar M (2014) Anti-Hyperglycemic and Antioxidant Effect of Saraca asoca (Roxb. De Wilde) Flowers in StreptozotocinNicotinamide Induced Diabetic Rats: A Therapeutic Study. J Bioanal Biomed S12: 003. doi:10.4172/1948-593X.S12-003

Page 5 of 5

24. Coskun O, Kanter M, Korkmaz A, Oter S (2005) Quercetin, a flavonoid antioxidant, prevents and protects streptozotocin-induced oxidative stress and beta-cell damage in rat pancreas. Pharmacol Res 51: 117-123.
25. Mishra SB, Verma A, Mukerjee A, Vijayakumar M (2012) Amaranthus spinosus L. (Amaranthaceae) leaf extract attenuates streptozotocin-nicotinamide induced diabetes and oxidative stress in albino rats: A histopathological analysis. Asian Pacific J Trop Biomed 2: s1647-s1652. 